\title{
Reforming Ukraine: Problems of Constitutional Regulation and Implementation of Human Rights
}

\author{
Oleksandr Petryshyn \\ National Academy of \\ Legal Sciences of Ukraine \\ Pushkinska 70, \\ Kharkiv 61024, Ukraine \\ E-mail: aprnu@ukr.net \\ Oleh Petryshyn \\ Scientific Research Institute of \\ State Building and Local Government \\ Chernyshevska 80, \\ Kharkiv 61002, Ukraine \\ E-mail: poe244@gmail.com
}

\begin{abstract}
The article focuses on current problems of human rights constitutional provision, protection and implementation in Ukraine in the context of the reforms aimed at Eurointegration. The aim is to brief in the historical aspects of the development of ideas and concepts of human rights in Ukraine, focus on the human rights provision of the active Constitution projected through the ongoing reforms and to expose the correlation between the rights enshrined and their actual implementation. The existing and possible future problems related to the regulation and realization of human rights in Ukraine's reform process are considered. The article reflects the problem of the value approach to human rights, which is directly related to the low level of legal culture and the insufficient level of development of civil society Ukraine. The work also analyses the amendments that have been made to the Constitution since the independence. While presenting the latest developments and drafts regarding the addressed issues, we try to look deeper into the problem, far beyond the formal and procedural concerns, addressing social and cultural barriers in understanding the importance and necessity of the problems under consideration not only by the leadership of the state but also by ordinary Ukrainians.
\end{abstract}

Keywords: constitutional process in Ukraine, European integration, human and civil rights and freedoms, reforming Ukraine 


\section{Introduction}

The volume of constitutional consolidation of rights and freedoms of man and citizen in Ukraine was constantly changing with the adoption of new constitutions. This process began with the adoption of the Constitution of the UNR (Ukrajinśka Narodna Respublika)—Ukrainian People's Republic-in 1918 and was continued by the constitution of the USSR (Ukrainian Soviet Socialist Republic) in 1919, and the subsequent ones in 1929, 1937 and 1978. Evidently, the concept of Soviet constitutions was not based on the idea of human rights as understood by the democratic society. Citizens' rights were provided by the authorities, but not recognized by them. Political rights were enshrined only formally, declaratively, while the priority was given to economic, social and cultural rights. The list of rights and freedoms did not correspond with the international documents and standards (Kerikmäe \& Nyman-Metcalf, 2012). During the Soviet era, the state authorized a significant number of violations of political and civil rights, such as the persecution of dissidents, restriction of the freedom of religion, confessions, the policy of mass repression, etc. However, the abovementioned documents played an important role in the history of the state of Ukraine and influenced the constitutional consolidation rights and freedoms of man and citizen at the present stage not only through overall legacy but through the Ukrainian people (Kerikmäe \& Chochia, 2016).

The processes of human rights development in freshly independent Ukraine mostly relate to historical processes of the late 1980s and early 1990s, which resulted in the abolition of the Soviet Union and the formation of many independent states, including Ukraine. One of the most critical objectives in the domestic human rights sphere at the time of the Soviet Union's collapse was the urge to reject the old system where the nationwide approach to regulation of human rights was limited to the perception of the latter as an instrument provided to certain groups of citizens to ensure and maintain the state order and the execution of the state policy.

It would be a mistake to define the start of the modern period of human rights development in Ukraine as the adoption of the Constitution of Ukraine (1996), when it is the Declaration on State Sovereignty (1990) which established the basis for a future new constitution of Ukraine, and according to which legislative acts to be adopted aimed at strengthening the legal status of a person and a citizen of Ukraine, nationalities and other categories of people living on the territory of Ukraine. 
After the adoption of the Constitution of Ukraine in 1996 (hereafter referred to as the Basic Law, the Constitution) and the ratification of the Convention for the Protection of Human Rights and Fundamental Freedoms of 1950 and the Protocols, the Verkhovna Rada (the Supreme Council) of Ukraine adopted the Principles of the State Policy of Ukraine in the Field of Human Rights (1999) in order to effectively implement the rights and freedoms. Expanding the provisions of the Constitution, the document stated that in Ukraine the protection of human rights and fundamental freedoms is the main responsibility of the state, state authorities, and local self-government. The state recognized the universality, interconnectedness, and interdependence of the rights and fundamental freedoms of man and citizen - recognizing the man, his life, and health, honor and dignity, inviolability and security as a highest social value.

The analysis of the proclaimed constitutional obligations of the state makes it possible to assert that the Constitution of Ukraine of the time may have been one of the most democratic constitutions in Europe. Such assessment was confirmed in the conclusions of the Venice Commission (European Commission for Democracy through Law), and through the approval of other international organizations, foreign countries and scholars in the field of constitutional law (Herasymenko, 2008). Yet the further expansion of the relevant provisions through legislation and practice have proven to be quite ambiguous.

\section{Reforms under Ukraine's Constitution: from paper to reality}

The Constitution of Ukraine delimits the fundamental rights and freedoms of human and citizen, and this approach comes unconventional for our constitutional legislation. Recognizing the distinction between the rights of a human and a citizen, the Basic Law thereby reinstated the universal values proclaimed in the Declaration of Independence of 1776, the Bill of Rights of 1791 (USA), and the Declaration of the Rights of Man and Citizen in 1789 (France). All articles of the second section of the Constitution of Ukraine "Rights, Freedoms and Responsibilities of Man and Citizen" consistently delimit the rights and freedoms on the basis of the above principle (Kushnirenko, 2001).

The document also reflects qualitative changes in the field of human and civil rights and freedoms in Ukraine. On the one hand, the content of traditional rights and freedoms (personal, political, socio-economic, and cultural) is enriched, and on the other, the list of rights and freedoms which are fixed at the constitutional level, is further expanded. This is evident through the inclusion of such rights as 
the right to the free development of personality (Art. 23), the right to life (Art. 27), the right to respect for human dignity (Art. 28), freedom of movement and free choice of place of residence (Art. 33), the right to entrepreneurial activity, which is not prohibited by law (Art. 42), the right to strike (Art. 44), the right to an adequate standard of living for themselves and their families (Art. 48), etc. (Constitution of Ukraine, 1996).

Ukrainian Basic Law, as well as the basic laws of some other countries, mostly apply a positive way of regulating human and civil rights and freedoms (Gerstenberg, 2012), but there is also a negative way of securing rights, that is, one that states that these rights should not be violated by anyone. For example, para. 3 of Art. 22 of our constitution states that "When adopting new laws or amending existing laws, the content and scope of existing rights and freedoms cannot be restricted (narrowed)." In the process of reforms, this formula is most often subjected to the negative influence of such, as elaborated more in this paper as we cover the most vulnerable groups of rights subjected to direct or possible violations through reforms implementation (Fokina, 2016).

1. The right to freedom of thought and religion. It presupposes, first and foremost, freedom from any ideological control. The man himself must decide what values to follow. The specification of the right to freedom of conscience and religion is the recognition by constitutions of the right to refuse military service on religious grounds (Heorhitsa, 2003) (Art. 34 of the Constitution of Ukraine). Considering the deplorable state of the Ukrainian Army as of the beginning of 2014, in order to stabilize the situation, it was decided to hold several waves of mobilization. During these, neither the government nor the parliament has taken adequate measures to remedy gaps in legislation in the field of the practical maintenance of a constitutional guarantee for the replacement of military duty by an alternate (non-military) service. The unclear situation led to the creation of a vicious circle, when mobilized believers were "trapped", given no options than to get mobilized or suffer a possible criminal punishment with the accusation of avoiding mobilization for military service. There are several court judgments acknowledging the mentioned constitutional right, yet, on the other hand, there are many examples when the courts ignore these provisions, substantiating their position with the absence of legislative norms that would directly permit the release from the mobilization for those whose beliefs do not allow the use of weapons.

2. Freedom of expression. These include freedom of speech, print, the right to receive information, and the freedom to disseminate information. The right 
to freedom of thought and speech, or rather, its guarantee is one of the main indicators of the democratic nature of society. However, it is not absolute and in accordance with Part 3 of Art. 34 of the Basic Law is subject to restriction in the interests of national security, territorial integrity or public order to prevent disturbances or crimes, to protect public health, to protect the reputation or rights of others, to prevent the disclosure of confidential information or to maintain authority and impartiality of justice. This is one of the many instances where the special conditions regarding the possibilities of limiting rights by the legislature and the circumstances in which the legislature can restrict the rights are very vague and too broad in nature. This gives the state authorities the opportunity to excessively interfere with the law. The provisions of this Article require a more understandable and clear approach in order to protect privacy on the one hand, and to ensure the implementation of the expressed rights without unlawful limitations (for example, determine the right to access information about the activities of public authorities as a separate and unrestricted, define personal life etc.). This gains significance in the wake of the anti-corruption reforms currently in force.

3. Political rights, which include: the right to freedom of association in political parties and public organizations, participation in trade unions (Art. 36); the right to participate in the management of state affairs, in nationwide and local referendums, the right to elect and be elected to bodies of state power and local self-government - the right to vote (Art. 38 ); the right to equal access to the civil service, as well as services in local self-government bodies (Art. 38), the right to send individual or collective appeals, or personally apply to bodies of state power, bodies of local selfgovernment. This block of rights has been heavily assaulted after the Revolution of Dignity. This includes the adoption of the Law of Ukraine 'On Conviction of Communist and National-Socialist (Nazi) Totalitarian Regimes in Ukraine and Prohibition of the Promotion of Their Symbols' (2015) of 09.04.2015, 317-VIII and the Law of Ukraine 'On Purification of Government' (2014) of 16.09.2014, 1682-VII. The first one was heavily criticized by the Office for Democratic Institutions and Human Rights for sanctioning the possibility of a real prison term for an entrepreneurial activity of producing various merchandise with the mentioned symbols. The second law had multiple flaws, such as creating a practice of collective legal responsibility, expanding the grounds for a dismissal of a judge (contrary to the provisions of Art. 126 of the Constitution), violating the generally accepted legal principle of the effect of the law in time (Art. 58 
of the Constitution: laws and other normative acts do not have a retroactive effect in time) through imposing a penalty in the form of a prohibition on occupying positions for a term of five years. The politicized character of the process of cleansing the government led to the fact that many former (and possibly corrupt) officials were able to return to their duties through a court judgment later on.

It is important to address the issue brought by the amendments to the Law of Ukraine 'On the Prevention of Corruption' (2014) of 14.10.2014, 1700VII, widening the range of persons obliged to submit yearly electronic declarations. In particular, the individuals who "carry out activities related to the prevention and counteraction of corruption", namely, public activists, experts, investigative journalists, citizens involved in anti-corruption measures, were included in the declarations. The inclusion of persons connected with the exercise of their right to freedom of association and the pursuit of certain activities (combating corruption) are discriminatory in terms of the activities of civic organizations and violate the European Convention on Human Rights and Fundamental Freedoms, the provisions of the Constitution of Ukraine on the right to freedom of association, labor, equal opportunities in the choice of profession and kind of employment, freedom of thought and words, free expression of their views and beliefs, privacy and non-interference in personal and family life.

4. Economic rights. Of these rights, probably the most important is the right to own and dispose of private property, which is secured from encroachment by both individuals and the authorities of the state by any legal means of remedy. The principle of the inviolability of private property was expressed in the prohibition of any constitutional norms of any confiscation or requisition otherwise than in the cases clearly established by law according to a court sentence (Hanin, 2006). However, recent amendments to the Criminal Code of Ukraine, the addition of Arts. 96/1 and 96/2 regarding special confiscation created a situation where the politicization of the decision-making process and the restriction of the rule of law bring up new corruption risks. This is evidenced by the fact that the court's judgment on the special confiscation regarding Viktor Yanukovych's assets was classified. The public danger of such activity can further severely affect the economy of Ukraine since there is a possibility of challenging this decision at the ECHR (European Court of Human Rights), which may lead to the need to return the assets that will lay on the state's budget, while the fate of the assets confiscated now is unknown. 
5. Health and social protection. Although being debatable, the latest achievements of the health care reform are also a subject to a contradiction when it comes to the realization of the Art. 49 of the Constitution that stipulates that "The state creates conditions of effective and accessible medical care. State and communal healthcare facilities provide medical care free of charge..." (Constitution of Ukraine, 1996) The inability or the reluctance to follow procedures and to amend the Constitution before implementing the abovementioned reform led to the creation of yet another situation of uncertainty using ways of circumvention, terminology manipulation and so on. It is hard to tell the future of the health care reform as of right now, but given the start it received, it does not look promising.

Talking about social protection, this constitutional right is the subject of constant protection by the Constitutional Court of Ukraine (2011). In fact, whenever the law on the State Budget for a given year abolishes or restricts certain social benefits, the Court finds such actions of the legislator unconstitutional (Barabash, 2012).

However, among the others, the recent pension reform violates at least four articles of the Constitution. Part 3 of Art. 22: regarding the narrowing of the content and scope of existing rights and freedoms (Konstytutsiia Ukrainy, 1996), as mentioned multiple times earlier, as well as Art. 24 (all citizens have equal constitutional rights and are equal before the law), Art. 46 (in the part of providing Ukrainians with pensions not lower than the subsistence level) and Art. 58 (in the part of the irreversibility of the laws in time).

Consequently, we have a situation where the state is not fully capable to guarantee the existing social rights, but a cardinal reform of the social sphere is not possible due to constitutional requirements, as well as their interpretation by the Constitutional Court of Ukraine (Barabash, 2009). Which is further complicated by the fact that Ukrainian authorities are constantly trying to experiment with social security issues. This is quite natural for a country with a fragile economy and insignificant financial resources. Obviously, it will be extremely difficult not only to rebuild the economic and legal component of the social protection system (which should have been the first post-independence priority) but also to change the stereotypical thinking on this issue by the citizens.

If the reforms in Ukraine, both from the moment of independence and the recent ones, were conducted without a single comprehensive course or vector, which was to be first reflected in the corresponding provisions of the Constitution 
(including the Section 2 'Rights, freedoms and obligations of a man and citizen'), what amendments were more successful?

From the adoption of the Constitution in 1996 and up to 2018, we can divide the constitutional process in Ukraine into 4 stages: (1) 1996-2004. The implementation of the provisions of the Constitution through the newly created legal acts (laws and regulations) and the system of bodies of state power and local self-government; (2) 2004-2013. Yet again politicized by the Orange Revolution and the subsequent devaluation of its ideals, the constitution was reformed in the context of the division of powers, and the process itself was characterized by a large number of violations, which subsequently led to a return to the 1996 Constitution; (3) 2014. On February 21, 2014, the Verkhovna Rada (The Supreme Council of Ukraine), on a revolutionary wave, adopted with a constitutional majority of 386 votes, without the decision of the profile committee, the draft law on the restoration of certain provisions of the Constitution of Ukraine (No. 4163), meaning that the Verkhovna Rada has put into effect the 2004 revision of the Constitution; and (4) 2015-2016 was characterized by the amendments regarding decentralization and the changes to the judicial system. It is worth mentioning that the latest reforms were, probably, the most successful and necessary, yet they still lack additional regulation and expansion.

This brings us to a situation where the amendment of a Basic Law of the state is possible only with the necessary political pressure and other interests involved. Based on the wrong goals and purposes later to be adopted and implemented with violations of procedures and ignoring the opinion of the authorized bodies, such reforms cannot contribute to the development of the state, law and its institutions.

Ukrainian legal doctrine features many reform concepts and developments in the sphere of domestic constitutional consolidation of human rights and provision of mechanisms for their implementation (Petryshyn, 2000). Among others, one of the most recent and interesting ones was the Joint Memorandum of Section II of the Constitution prepared by the Working Group on the Rights, Freedoms, and Duties of Man and Citizen on July 15, 2015. This working group (Pylypenko, 2016), consisting of leading experts in the field of state building, human rights, international, civil and criminal law prepared a detailed draft of amendments to the Section II based on the provisions of the major international human rights instruments and the practice of the European Court of Human Rights, offering a plan of actions, featuring, among the others:

1) Discover the notion of human dignity and expand the state duties associated with its respect and protection; 
2) Fully deny the possibility of conviction to the capital punishment within the framework of the vested right to life,

3) Specify the provisions on the prohibition of torture and assure the concepts of "physical and spiritual integrity";

4) Implement the standards of international conventions on the prohibition of slavery and forced labor, human trafficking;

5) Improve the provisions associated with the realization of the right to freedom and personal inviolability by reducing the maximum period of detention to forty-eight hours and securing the state compulsory compensation for moral and material harm to the detainee contrary to the provisions of Article 29 of the Constitution (Art. 26 of the draft);

6) Recognize a wide range of children's rights: the right to protection and care, free expression of views, direct contact with both parents and the like;

7) Further polish the provisions on freedom of thought, conscience, and religion, as well as freedom of speech, prohibition of discrimination and many others.

\section{Conclusions}

The situation around the constitutional recognition of human rights in Ukraine brings many questions we can only assume answers to. Was Section 2 of the Constitution created with an understanding of the problems that could arise with the realization of such rights in the future? It seems that the overall confusion and political debates of the past still haunt us even up to date. Surely, it is impossible for a young independent state to predict the consequences, yet it seems that nothing was done to at least mitigate the possible negative effects. What can be the result of ongoing reforms if they initially have provisions that are contrary to the provisions of the Constitution? Spreading more uncertainty and legal contradictions for one thing, up to possible repeal and abolition of some of the acts. This will surely affect the lives of Ukrainians for years to come. If changes to the Constitution have already been made without the relevant conclusions of the Constitutional Court of Ukraine, what role will it play in the implementation of the recently introduced right of constitutional complaint? As of 2018, the mechanism of constitutional complaint is still in its early stages, yet the formation process of the Court itself leaves a lot of questions, and its activity in the past is also highly politicized and ambiguous in terms of law and Constitution.

Regarding practical implementation and real protection of constitutional rights, it is impossible to limit ourselves here simply by rewriting existing regulations 
or by creating special groups, officials monitoring such implementation, etc. We must understand that this has nothing to do with Ukraine being a younger independent state as well. There are many examples of post-Soviet counties performing better and showing more economic and political growth than some of the western European states.

What needs to be understood is that the problem of the reality of the assigned rights is primarily connected with the low level of legal culture, the absence of the rule of law and democracy, the construction of a pseudo-market economy based on large and petty corruption, and the lack of understanding of the common good for the state and all its inhabitants. This problem is aggravated by the newly emerged problems of separatism, the problems with the establishment of Ukraine as a single democratic state, in which the constitution becomes an effective tool, and not a set of theses, the implementation of which is impossible.

In Ukraine, human rights and freedoms have not yet become truly the highest value of the state. This is due to the previous history, modern problems of the country, as well as the policy of the current government, which has not yet overcome the traditions of human underestimation that have evolved over many centuries. In addition, civil society in the face of political and other institutions is not sufficiently active in protecting the rights and freedoms of the individual, not to mention the pressure that is being put on such entities (Kerikmäe et al., 2016).

It is evident that the development of Ukraine in the direction of establishing the rule of law is one of the key prerequisites for establishing in the consciousness of Ukrainian society the corresponding values of the legal state, the general expression of which should be the developed legal culture of Ukrainian citizens. Formal perception of the respective political and legal institutions, as well as legal norms, developed political and legal systems of the world with a view to their adaptation to domestic realities without a fundamental change in the stereotypes of legal thinking and behavior condemns the rule of law in Ukraine to declarative. In this sense, the specialization of the corresponding culture of legal thinking, thinking within the categories of human rights is acquired by the citizens of Ukraine.

Contemporary events in Ukraine, complex and ambiguous in their content, continue to support the idea of the exceptional importance of the comprehensive protection of fundamental rights and freedoms as defined by the Basic Law, as well as the need to prevent legal nihilism in the human rights and law-enforcement spheres. In this sense, it is important to remember the old axiom “one person's 
freedom ends where another's begins". Therefore, the respect of citizens for their own rights and freedoms of other people as the highest social value is an important condition for solving the crisis in Ukraine. The constitutional rights and freedoms themselves, and the guarantees of their implementation should become the cornerstone for the further development of state formation and lawmaking, consolidation of democracy and the rule of law, strengthening of the authority of our state in the international arena.

Prof. Oleksandr Petryshyn is President of the National Academy of Legal Sciences of Ukraine and an active member (academician) of the same institution. His research interests include methodology of legal research, civil society, rights and freedoms of man and citizen, rule of law, general theory of civil service. He has repeatedly participated in the drafting of amendments and additions to the Constitution of Ukraine, the Laws of Ukraine 'On Civil Service', 'Concept of Reforming Criminal Justice in Ukraine', etc.

Oleh Petryshyn, Candidate of Sciences, heads the Comparative Law Sector of the Scientific Research Institute of State Building and Local Government. Research interests include international and domestic human rights regulation, comparative studies regarding human rights and state-building in general.

\section{References}

Barabash, Yu. H. (2009), 'Pravova polityka u sferi prav liudyny: shliakhy pidvyshchennia efektyvnosti' [Legal human rights policy: ways to increase effectiveness], Pravo Ukrainy, vol. 4, pp. 55-61. [In Ukrainian]

Barabash, Yu. H. (2012), Konstytutsiina yurysdyktsiia: pidruchnyk [Constitutional jurisdiction: textbook], Kharkiv: Pravo. [In Ukrainian]

Constitution of Ukraine (1996), Konstitucia Ukrainy, 28.06.1996. Retrieved from http://zakon2.rada.gov.ua/laws/show/254к/96-вр [accessed 28 Apr 2018]

Declaration of State Sovereignty of Ukraine (1990), Deklaratsiia pro derzhavnyi suverenitet Ukrainy, 16.07.1990. Retrieved from http://zakon0.rada.gov.ua/laws/ show/55-12 [accessed 28 Apr 2018]

Fokina, M. O. (2016), Prava i svobody liudyny yak obiekt konstytutsiino-pravovoho rehuliuvannia [Human rights and freedoms as an object of constitutional and legal regulation], $\mathrm{PhD}$ thesis. [In Ukrainian]

Gerstenberg, O. (2012), 'Negative / positive constitutionalism, "fair balance", and the problem of justiciability,' Int. Jnl. of Constitutional Law, vol. 10, no. 4. https://doi.org/10.1093/icon/mor085 
Hanin, O. V. \& Zakharov, V. V. (2006), Konstytutsiine pravo zarubizhnykh krain: khrestomatiia [Constitutional law of foreign countries: textbook], Tambov: Tambov. derzh. tekhn. un-ta. [In Ukrainian]

Heorhitsa, A. Z. (2003), Konstytutsiine pravo zarubizhnykh krain [Constitutional law of foreign countries]. Retrieved from http://lection.com.ua/pravo/kpzk/ sistema-konstitutsiynih-prav-svobod-i-o bov'yazkiv-lyudini-i-gromadyaninakonstitutsiyne-pravo-zarubizhnih-krayin [accessed 15 Apr 2018]

Herasymenko, S. Ye. (2008), 'Konstytutsiina reforma i prava liudyny' [Constitutional reform and human rights], Stratehichni Prioritety, vol. 1, no. 7, pp. 22-25. [In Ukrainian]

Judgement of the Constitutional Court of Ukraine (case concerning the compliance of the Constitution of Ukraine (constitutionality) of clause 4 of Section VII 'Closed Provision' of the Law of Ukraine 'On the State Budget of Ukraine of 2011')] (2011), Rishennia Konstytutsiinoho Sudu Ukrainy (sprava shchodo vidpovidnosti Konstytutsii Ukrainy (konstytutsiinosti) punktu 4 rozdilu VII «Prykintsevi polozhennia» Zakonu Ukrainy «Pro Derzhavnyi biudzhet Ukrainy na 2011 rik»), 26.12.2011. Retrieved from http://zakon4.rada.gov.ua/laws/show/v020p710-11 [accessed 25 Apr 2018]

Kerikmäe, T. \& Chochia, A., eds. (2016), Political and Legal Perspectives of the EU Eastern Partnership Policy, Cham: Springer International Publishing. https://doi. org/10.1007/978-3-319-27383-9

Kerikmäe, T.; Hamulak, O. \& Chochia, A. (2016), 'A historical study of contemporary human rights: deviation or extinction?' Acta Baltica Historiae et Philosophiae Scientiarum, vol. 4, no. 2, pp. 98-115. https://doi.org/10.11590/abhps.2016.2.06

Kerikmäe, T. \& Nyman-Metcalf, K. (2012), 'Less is more or more is more? Revisiting universality of human rights,' International and Comparative Law Review, vol. 12, no. 1, pp. 35-51. https://doi.org/10.1515/iclr-2016-0077

Kushnirenko, O. H. (2001), 'Prava i svobody liudyny i hromadianyna' [The rights and freedoms of man and citizen], vol. 1, Kharkiv: Fakt. [In Ukrainian]

Law of Ukraine 'Principles of the State Policy of Ukraine in the Field of Human Rights', Pro Zasady derzhavnoi polityky Ukrainy v haluzi prav liudyny, Postanova Verkhovnoi Rady Ukrainy, 17.06.1999, The decree of the Supreme Council of Ukraine. Retrieved from http://zakon5.rada.gov.ua/laws/show/757-14 [accessed 28 Apr 2018]

Law of Ukraine 'On Conviction of Communist and National-Socialist (Nazi) Totalitarian Regimes in Ukraine and Prohibition of the Promotion of Their Symbols', Pro zasudzhennia komunistychnoho ta natsional-sotsialistychnoho (natsystskoho) totalitarnykh rezhymiv $v$ Ukraini ta zaboronu propahandy yikhnoi symvoliky, Zakon Ukrainy, 09.04.2015. Retrieved from http://zakon0.rada.gov.ua/laws/ show/317-19 [accessed 28 Apr 2018] 
Law of Ukraine 'On Prevention of Corruption', Pro zapobihannia korruptsii, Zakon Ukrainy, 14.10.2014. Retrieved from http://zakon0.rada.gov.ua/laws/show/170018 [accessed 28 Apr 2018]

Law of Ukraine 'On Purification of Government', Pro ochyshchennia vlady, Zakon Ukrainy, 16.09.2014. Retrieved from http://zakon0.rada.gov.ua/laws/show/168218 [accessed 28 Apr 2018]

Murashyn, H. O. (1998), 'Konstytutsiia Ukrainy: deiaki aspekty yii realizatsii' [The Constitution of Ukraine: some aspects of its implementation], in Teoretychni Ta Praktychni Pytannia Realizatsii Konstytutsii Ukrainy: Problemy, Dosvid, Perspektyvy: Materialy Nauk.-Prakt. Konf. [Theoretical and practical questions of the implementation of the Constitution of Ukraine: problems, experience, perspectives: materials of sciences. conf.], pp. 47-49. [In Ukrainian]

Petryshyn, O. V. (2000), 'Prava liudyny yak fundamentalna tsinnist pravovoi demokratychnoi derzhavnosti' [Human rights as a fundamental value of the legal democratic statehood], in Aktualni Problemy Formuvannia Pravovoi Derzhavy $v$ Ukraini: Materialy Nauk.-Prakt. Konf., no. 1, pp. 39-42. [In Ukrainian]

Pylypenko, V. (2016), 'Prava liudyny: shcho proponuiut zminyty eksperty Konstytutsiinoi komisii?' [Human rights: What do the Constitutional Commission experts suggest to change?] LIGA.Blogi, 19 February. Retrieved from http://blog. liga.net/user/vpylypenko/article/21039 [accessed 28 Apr 2018]

Rabinovych, P. M.; Hudyma, D. A. \& Dudash, V. O. (2008), Prava liudyny $i$ hromadianyna: mozhlyvosti udoskonalennia konstytutsiinykh harantii [Rights of man and citizen: Opportunities for improving constitutional guarantees], Lviv: Malyi vydav. tsentr yurud. fakultetu LNU im. Ivana Franka. [In Ukrainian]

Rechytskyi, V. (2015), 'Prava liudyny v Ukraini: krytychyi pohliad na dosiahnute' [Human rights in Ukraine: a critical view on the achievements], Pravo Ukrainy [Law of Ukraine], no. 10, pp. 79-86. [In Ukrainian]

Reporting memorandum on the drafting of a bill on amending and supplementing Chapter II of the current Constitution of Ukraine, prepared by the Working Group of the Constitutional Commission (2015), Zvitnyi memorandum z pryvodu rozrobky zakonoproektu pro vnesennia zmin ta dopovnen do Rozdilu II chynnoi Konstytutsii Ukrainy, pidhotovlenoho Robochoiu hrupoiu Konstytutsiinoi Komisii stanom na 15 lypnia 2015 roku, 15.07.2015. Retrieved from https://helsinki.org. ua/publications/zvitnyj-memorandum-z-pryvodu-rozrobky-zakonoproektu-provnesennya-zmin-ta-dopovnen-do-rozdilu-ii-chynnoji-konstytutsiji-ukrajinypidhotovlenoho-robochoyu-hrupoyu-konstytutsijnoji-komisiji-stanom-na-1/ [accessed 28 Apr 2018] 